\title{
Optical Analysis of Planar Multicrystalline Perovskite Solar Cells
}

\author{
Maarten van Eerden,* Manoj Jaysankar, Afshin Hadipour, Tamara Merckx, \\ John J. Schermer, Tom Aernouts, * Jef Poortmans, and Ulrich W. Paetzold*
}

Organometal halide perovskites are attracting strong interest as light-harvesting absorber materials in single- and multijunction solar cells. In order to advance the technology, careful optical design of the device architecture and elaborate analysis of optical losses are essential. In this work, a detailed optical analysis of semitransparent and opaque planar $\mathrm{CH}_{3} \mathrm{NH}_{3} \mathrm{Pbl}_{3}$ solar cells is reported. Using a combination of variable-angle spectroscopic ellipsometry and spectrophotometry data, the complex refractive indices of all involved materials in the device architecture are accurately determined, taking the underlying layer stack explicitly into account. The optical properties of partial and complete layer stacks of solar cells, comprising $\mathrm{CH}_{3} \mathrm{NH}_{3} \mathrm{Pbl}_{3}$ films with different $\mathrm{CH}_{3} \mathrm{NH}_{3} \mathrm{Pbl}_{3}$ surface topography roughnesses, are simulated using the transfer-matrix method. Very good agreement between simulated and experimental data is demonstrated. Sub-bandgap absorption is observed in $\mathrm{CH}_{3} \mathrm{NH}_{3} \mathrm{Pbl}_{3}$ layer stacks, which is by means of a ray-tracing model shown to be related to diffuse scattering at the multicrystalline $\mathrm{CH}_{3} \mathrm{NH}_{3} \mathrm{Pbl}_{3} /$ air interface. Finally, the optical losses of all layers are discriminated for opaque and semitransparent $\mathrm{CH}_{3} \mathrm{NH}_{3} \mathrm{Pbl}_{3}$ solar cells and four-terminal perovskite/Si tandem solar cells.

\section{Introduction}

Organometal halide perovskites have emerged as excellent absorber materials for thin-film photovoltaics. The power conversion efficiency (PCE) of perovskitebased solar cells has risen at an unprecedented rate from an initial 3.8\% upon its inception in $2009^{[1]}$ to a certified $22.1 \%$ in early 2016. ${ }^{[2]}$ The material possesses the $\mathrm{ABX}_{3}$ crystal structure, where $\mathrm{A}$ is a small organic cation, B is a cationic group 14 metal, and $\mathrm{X}$ is a halide anion. Varying the perovskite constituents offers exciting flexibility in the optoelectronic material properties and device characteristics. The highest PCEs, for example, have been obtained using mixed-A-site-cation systems ${ }^{[3-6]}$ while bandgap tuning over a wide spectral range is possible in mixed-halide systems. ${ }^{[7-10]}$ Methylammonium lead triiodide $\left(\mathrm{CH}_{3} \mathrm{NH}_{3} \mathrm{PbI}_{3}\right)$ represents the most studied perovskite material, owing to its excellent material properties for photovoltaic applications such as a favorable

M. van Eerden, Dr. J. J. Schermer

Faculty of Science

Department of Applied Materials Science

Radboud University Nijmegen

Heyendaalseweg 135, 6525 AJ Nijmegen, The Netherlands

E-mail:m.vaneerden@science.ru.nl

M. van Eerden, M. Jaysankar, Dr. A. Hadipour, Dr. T. Merckx,

Dr. T Aernouts, Prof. J. Poortmans, Dr. U. W. Paetzold

Thin-Film Photovoltaics

IMEC - Partner in Solliance

Kapeldreef 75, 3001 Heverlee, Belgium

E-mail: aernouts@imec.be;

Ulrich.paetzold@kit.edu

Prof. J. Poortmans

Department of Materials Engineering

Universiteit Hasselt

3500 Hasselt, Belgium

Dr. U. W. Paetzold

Institut für Mikrostrukturtechnik

Karlsruher Institute für Technologie

Hermann-von-Helmholtz-Platz 1, 76344 Eggenstein-Leopoldshafen,

Germany

The ORCID identification number(s) for the author(s) of this article can be found under https://doi.org/10.1002/adom.201700151.

DOI: 10.1002/adom.201700151 bandgap of about $1.55 \mathrm{eV},{ }^{[11,12]}$ a high absorption coefficient,,${ }^{[12,13]}$ long charge-carrier diffusion lengths, ${ }^{[14,15]}$ and a remarkably low difference between experimentally realized open-circuit voltage $\left(V_{\mathrm{OC}}\right)$ and the perovskite bandgap potential $\left.\left(E_{\mathrm{g}} / \mathrm{q}\right)\right)^{[16]}$

An exciting prospect of perovskite solar cells is its application in multijunction architectures in combination with established, low-bandgap photovoltaic technologies, such as crystalline silicon (c-Si) or copper-indium-gallium-(di)selenide (CIGS). This concept potentially allows PCEs beyond the ShockleyQueisser limit of single-junction solar cells. ${ }^{[17-19]}$ Experimentally, multijunction architectures comprising perovskite solar cells as the top subcell have thus far shown promising results toward realizing this goal. ${ }^{[20-26]}$ An ongoing challenge in this research field lies in developing high-performance perovskite photovoltaic devices with high sub-bandgap transmittance, which requires judicious electronic as well as optical device optimization. ${ }^{[22,27,28]}$ In this regard, parasitic absorption losses that have been reported in literature should be eliminated. ${ }^{[29-31]}$

Typically, a planar perovskite solar cell consists of a thinfilm layer stack comprising a photoactive perovskite layer, two electrode layers, and two selective charge transport layers that determine the electronic as well as the optical properties of the device. Reflections and interferences within the thin-film 
layer stack govern light in- and outcoupling, the electric field distribution, and absorption profile. To further develop the perovskite photovoltaic technology, both in single- and in multijunction architectures, careful optical design, analysis of optical losses, and advanced light management are crucial. The transfer-matrix method (TMM) allows modeling of the optical properties of planar, stratified, thin-film layer stacks by rigorously solving Maxwell's equations at each interface. Using the complex refractive index and layer thicknesses of all relevant materials as input, it presents a route to optimize the optical design of thin-film optoelectronic devices, which was demonstrated in rigorous studies of mesostructured perovskite solar cells, ${ }^{[32,33]}$ planar perovskite solar cells with varying perovskite morphologies, ${ }^{[34]}$ and nanostructured devices. ${ }^{[35]}$

A key aspect that is not reflected in TMM studies of planar devices is light scattering in rough perovskite layers. The surface roughness of perovskite layers is closely related to the morphology, both of which depend on the deposition route ${ }^{[20,36-39]}$ and the underlying substrate. ${ }^{[40,41]}$ The influence of the morphology of perovskite layers on the electro-optical properties was recently demonstrated in an extensive study by Correa-Baena et al. $^{[34]}$ In addition, the importance of high-quality, smooth perovskite films for an accurate optical analysis was stressed in recent work, where complex refractive indices of a range of mixed $\mathrm{Pb}-\mathrm{Sn}$ perovskites were accurately determined, and the application of these materials in perovskite-on-perovskite tandems was discussed. ${ }^{[42]}$ Other optical analyses of $\mathrm{CH}_{3} \mathrm{NH}_{3} \mathrm{PbI}_{3}$ solar cells were reported; however, they focused only on the short-wavelength range relevant for opaque cells, ${ }^{[43-45]}$ were hampered by roughness of the front transparent conducting oxide (TCO), ${ }^{[31]}$ or did not present optical simulations of full $\mathrm{CH}_{3} \mathrm{NH}_{3} \mathrm{PbI}_{3}$ solar cells to verify their optical data. ${ }^{46-50]}$

Building upon these initial studies, our work presents a detailed optical analysis and direct comparison of semitransparent and opaque $\mathrm{CH}_{3} \mathrm{NH}_{3} \mathrm{PbI}_{3}$ solar cells over a wide spectral range from 330 to $1170 \mathrm{~nm}$, which is of high importance for multijunction devices such as perovskite/Si tandem solar cells. We use a rigorous approach of simultaneously fitting variableangle spectroscopic ellipsometry (VASE) data and reflectance and transmittance data to acquire accurate optical constants of the materials in a commonly employed solar cell architecture. Our analysis takes the influence of the underlying layer stack explicitly into account. The accuracy of our data is confirmed by optically simulating partial and complete $\mathrm{CH}_{3} \mathrm{NH}_{3} \mathrm{PbI}_{3}$ solar cell layer stacks and showing excellent agreement with experimental data. Furthermore, we show that $\mathrm{CH}_{3} \mathrm{NH}_{3} \mathrm{PbI}_{3}$ surface roughness may cause anomalous sub-bandgap absorption by increasing parasitic absorption in the underlying layers through diffuse scattering. Finally, based on our accurate optical data set, we quantify and discriminate the optical losses relevant for semitransparent and opaque $\mathrm{CH}_{3} \mathrm{NH}_{3} \mathrm{PbI}_{3}$ solar cells and fourterminal perovskite/Si tandem solar cells.

\section{Results and Discussion}

\subsection{Characterization of Individual Materials}

The solar cell architectures studied comprise an indium-tinoxide (ITO)-coated glass substrate, e-beam deposited $\mathrm{TiO}_{2}$, spin-coated $\mathrm{CH}_{3} \mathrm{NH}_{3} \mathrm{PbI}_{3}$, and spin-coated spiro-OMeTAD $\left(2,2^{\prime}, 7,7^{\prime}\right.$-tetrakis (N, N-di-p-methoxyphenyl-amine) $9,9^{\prime}$ spirobifluorene). Sputtered ITO and thermally evaporated gold rear electrodes complete the semitransparent and opaque solar cells, respectively. This nip-architecture is widely used for planar perovskite solar cells, as it has the merit that the ITO-coated glass substrate maintains its high electronic quality when processed at high temperatures. In addition, when applied in a solar module, the ITO-coated glass may serve as the front glass cover of the module. In order to determine the optical constants of the solar cell materials, we acquire VASE data under different angles of incidence $\left(55^{\circ}-75^{\circ}\right)$ and spectrophotometric data from films of the materials on $\mathrm{Si} / \mathrm{SiO}_{2}$ and glass substrates. The ITO-coated glass substrates used for semitransparent and opaque solar cells are not identical and are therefore characterized separately. A schematic of the optical models used to fit the acquired data is shown in Figure S1 (Supporting Information). Surface roughness is considered as an effective medium according to the Bruggeman effective medium approximation (BEMA). ${ }^{[51]}$ We employ oscillator models consistent with Kramers-Kronig transformations to model the dispersion of the optical constants and fit the model parameters using a root mean squared error (RMSE) minimizer. The TMM is used to simulate reflectance, transmittance, and absorptance spectra of the layers on glass, using identical optical models as used during ellipsometry fitting, and we maximize overall agreement of modeled VASE- and TMM-based data with experimental data. Additional details on the ellipsometric analysis are provided in the Supporting Information, along with the ellipsometric data (Figures S2-S5, Supporting Information) as well as reflectance, transmittance, and absorptance data (Figures S6 and S7, Supporting Information) of the characterized materials.

The complex refractive index spectra of the studied materials are shown in Figure 1. The optical constants of gold are extracted from literature ${ }^{[52]}$ and are shown in Figure S8 (Supporting Information). Figure 1a shows the optical constants of the different ITOs studied. The in-house sputtered rear ITO has a higher $n$ and lower $k$ for long wavelengths than the commercially provided front ITOs (Figure 1a), which is indicative of a lower free carrier density. ${ }^{[53-55]}$ In view of the fact that we are able to produce high-efficiency, semitransparent solar modules with good fill factors using this in-house sputtered ITO, the low $k$ for long wavelengths is promising for fabricating multijunction architectures. ${ }^{[23]}$ The optical constants of the electron transport material $\mathrm{TiO}_{2}$, shown in Figure 1b, are in line with previous reports of e-beam deposited $\mathrm{TiO}_{2} \cdot{ }^{[49,56]}$ Figure $1 \mathrm{c}$ shows the optical constants of the hole transport material spiroOMeTAD, doped by exposure to $\mathrm{O}_{2}$ for different periods of time (details on the doping mechanism are given in refs. [57,58]). A peak in the extinction coefficient, around $500 \mathrm{~nm}$, emerges for increasing the doping levels, which is in agreement with the reported doping mechanism. ${ }^{[57-59]}$ The magnitude of this peak varies only slightly upon extending the doping time from 24 to $60 \mathrm{~h}$, indicating that the doping reaction is already close to completion after $24 \mathrm{~h}$. Doping induces a minor and constant increase in the real refractive index $n$ of spiro-OMeTAD for $\lambda>450 \mathrm{~nm}$. These results shed light on the optical properties of the hole transport material spiro-OMeTAD, which is widely used in high-efficiency perovskite solar cells, ${ }^{[60-62]}$ 

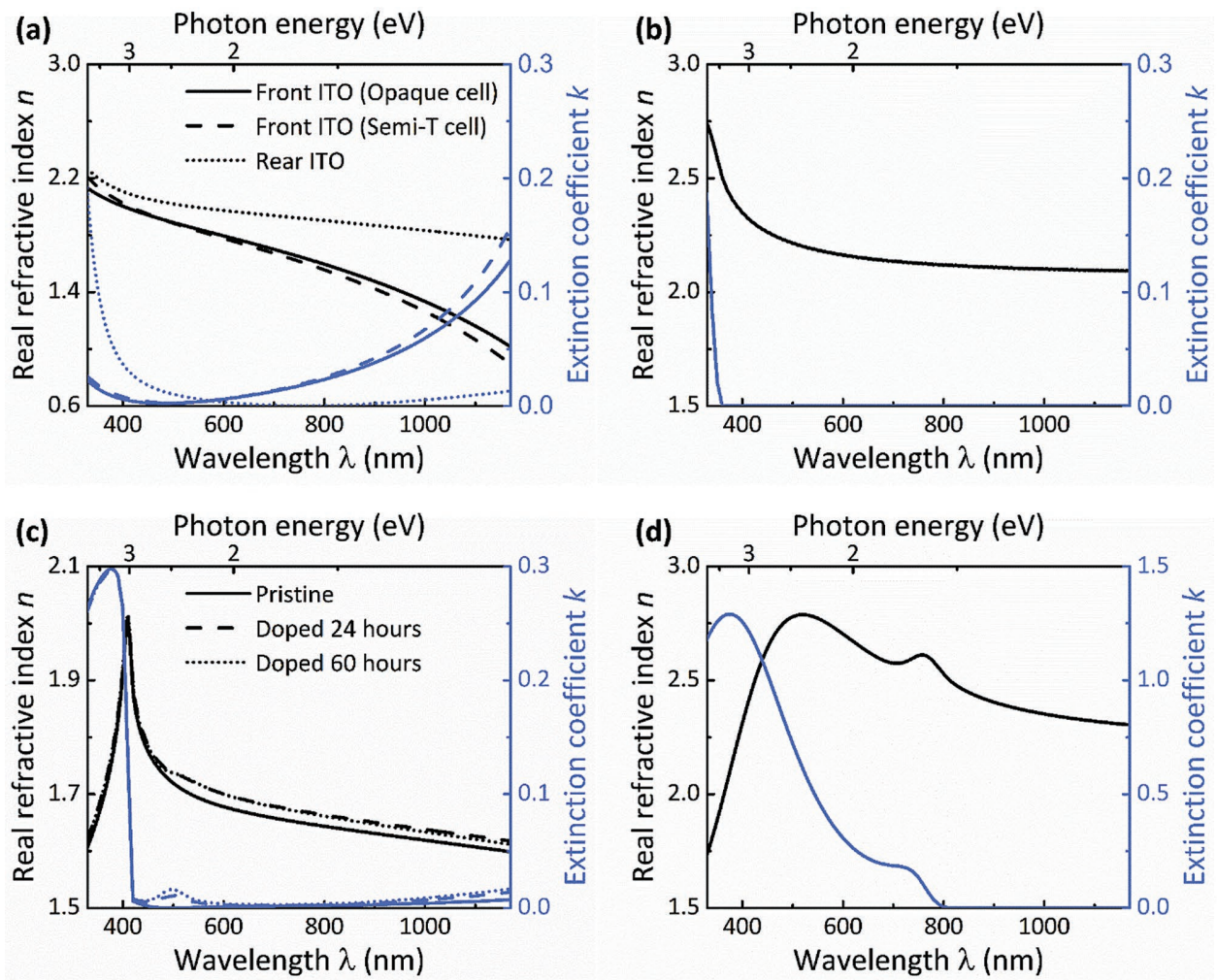

Figure 1. Optical constants $(n, k)$ of the materials used in the solar cells studied in this work. a) Front and rear ITO of the semitransparent solar cell and front ITO of the opaque solar cell. b) E-beam deposited $\mathrm{TiO}_{2}$. c) Spiro-OMeTAD doped by $\mathrm{O}_{2}$-exposure in a controlled humidity environment $(\mathrm{RH} \approx 20 \%)$. d) $\mathrm{CH}_{3} \mathrm{NH}_{3} \mathrm{Pbl}_{3}$.

for device-relevant processing conditions. Figure $1 \mathrm{~d}$ shows the optical constants of $\mathrm{CH}_{3} \mathrm{NH}_{3} \mathrm{PbI}_{3}$. For the optical characterization, $\mathrm{CH}_{3} \mathrm{NH}_{3} \mathrm{PbI}_{3}$ was deposited onto $\mathrm{TiO}_{2}$-coated substrates, analogous to its application in actual devices. ${ }^{[36]}$ Since extensive surface roughness might hamper accurate ellipsometric analyses, we prepared a $\mathrm{CH}_{3} \mathrm{NH}_{3} \mathrm{PbI}_{3}$ film with a relatively low $R_{\mathrm{rms}}$ of $\approx 10 \mathrm{~nm}$ through the antisolvent route and used this film to acquire the optical data. ${ }^{[3]}$ Our spectrophotometric measurements show anomalous sub-bandgap absorption, which was even more pronounced in a $\mathrm{CH}_{3} \mathrm{NH}_{3} \mathrm{PbI}_{3}$ film with an $R_{\text {rms }}$ of $50 \mathrm{~nm}$ prepared through a one-step processing method (see Figure S9 of the Supporting Information). ${ }^{[36]}$ The extracted optical constants agree well with previous reports from in-depth optical characterizations of $\mathrm{CH}_{3} \mathrm{NH}_{3} \mathrm{PbI}_{3}$ (Figure S10, Supporting Information), especially in the $\mathrm{CH}_{3} \mathrm{NH}_{3} \mathrm{PbI}_{3}$ sub-bandgap wavelength range $(\lambda>800 \mathrm{~nm}) .{ }^{[13,45]}$ The $\mathrm{CH}_{3} \mathrm{NH}_{3} \mathrm{PbI}_{3}$ extinction coefficient following from our ellipsometric analysis vanishes in this wavelength range, a result that is in agreement with accurate measurements of the absorption coefficient of $\mathrm{CH}_{3} \mathrm{NH}_{3} \mathrm{PbI}_{3}$ using photothermal deflection spectroscopy. ${ }^{[12]}$ The measured sub-bandgap absorption is therefore unlikely to be caused by absorption in $\mathrm{CH}_{3} \mathrm{NH}_{3} \mathrm{PbI}_{3}$. However, we do measure significant absorption in the bare substrates for the $\mathrm{CH}_{3} \mathrm{NH}_{3} \mathrm{PbI}_{3}$ sub-bandgap wavelength range (Figure S11, Supporting Information). Thus, we argue that total internal reflection of photons reflecting diffusively at the rough $\mathrm{CH}_{3} \mathrm{NH}_{3} \mathrm{PbI}_{3}$ /air interface might augment the absorption that is present in the bare substrates. In order to provide support for this hypothesis, we developed a simple ray-tracing model that predicts the extra absorption due to diffuse scattering at the $\mathrm{CH}_{3} \mathrm{NH}_{3} \mathrm{PbI}_{3} /$ air interface of $\mathrm{CH}_{3} \mathrm{NH}_{3} \mathrm{PbI}_{3}$ layer stacks. Diffuse scattering is incorporated in this model through

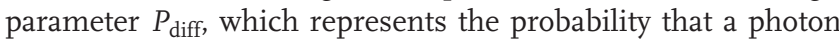
reflecting off the $\mathrm{CH}_{3} \mathrm{NH}_{3} \mathrm{PbI}_{3}$ /air interface reflects diffusively. Parameter $A_{1}$ is used to describe the absorption per pass, which is assumed to be independent of the path length through the layer stack. Additional details on the ray-tracing model are provided in the Supporting Information. Figure 2 shows the extra absorption in $\mathrm{CH}_{3} \mathrm{NH}_{3} \mathrm{PbI}_{3}$ layer stacks due to diffuse scattering at the $\mathrm{CH}_{3} \mathrm{NH}_{3} \mathrm{PbI}_{3} /$ air interface as a function of $A_{1}$ and $P_{\text {diff, }}$ predicted by the ray-tracing model. The extra absorption in the substrate due to total internal reflection reaches $>5 \%$ when $A_{1}>0.1$ and $P_{\text {diff }} \approx 0.5$. Measurements of diffuse reflectance of $\mathrm{CH}_{3} \mathrm{NH}_{3} \mathrm{PbI}_{3}$ layer stacks with different $R_{\mathrm{rms}}$ (Figure $\mathrm{S} 12$, Supporting Information) confirm that values of $P_{\text {diff }} \approx 0.5$ can be approached in practice. This is an important aspect to take into account when interpreting and analyzing absorption measurements of $\mathrm{CH}_{3} \mathrm{NH}_{3} \mathrm{PbI}_{3}$ layer stacks. Strong scattering at a rough $\mathrm{CH}_{3} \mathrm{NH}_{3} \mathrm{PbI}_{3} /$ air interface can cause anomalies such as augmented absorption and destruction of coherence within the thin-film layer stack, which should be recognized and interpreted correctly. Our model provides a tool to assess the severity of these effects through readily available measurements of total and diffuse reflection. It should be noted that the raytracing model is simplified, neglecting (total internal) reflection at intermediate interfaces, interference effects, the path length 


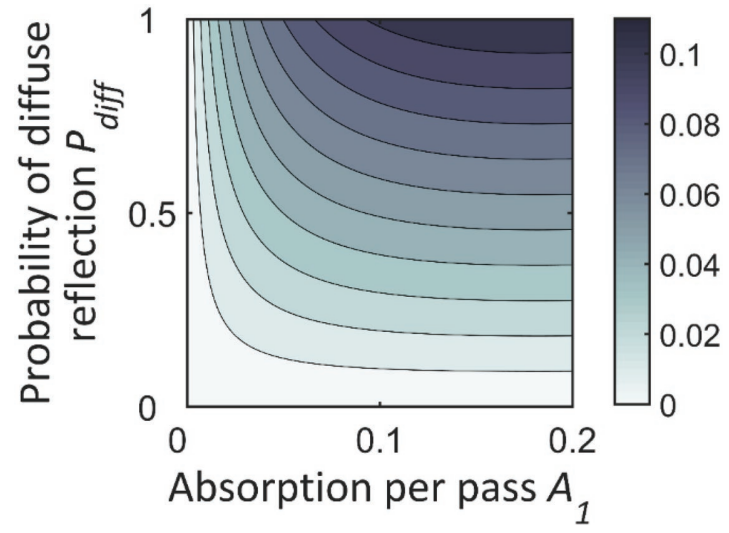

Figure 2. Extra absorption due to total internal reflection of diffusively scattered photons at the $\mathrm{CH}_{3} \mathrm{NH}_{3} \mathrm{Pbl}_{3}$ /air interface of $\mathrm{CH}_{3} \mathrm{NH}_{3} \mathrm{Pbl}_{3}$ layer stacks, predicted by the ray-tracing model.

difference of diffusively scattered photons, photon tunneling, and assuming Lambertian scattering at rough interfaces. Nevertheless, the model clearly allows us to determine qualitatively the effect of $\mathrm{CH}_{3} \mathrm{NH}_{3} \mathrm{PbI}_{3}$ surface roughness on the sub-bandgap absorption in multiple $\mathrm{CH}_{3} \mathrm{NH}_{3} \mathrm{PbI}_{3}$ layer stacks (Figure S9, Supporting Information). It shall be noted that our model shows that the sub-bandgap absorption in $\mathrm{CH}_{3} \mathrm{NH}_{3} \mathrm{PbI}_{3}$ layer stacks arises from increased parasitic absorption in the layers underlying the $\mathrm{CH}_{3} \mathrm{NH}_{3} \mathrm{PbI}_{3}$ thin film. High-quality, smooth $\mathrm{CH}_{3} \mathrm{NH}_{3} \mathrm{PbI}_{3}$ films exhibit negligible sub-bandgap absorption themselves. ${ }^{[12]}$

\subsection{Transfer-Matrix-Based Optical Simulations}

\subsubsection{Entire Layer Stack of Solar Cells}

Based on the previously determined complex refractive index data, we optically simulate four different $\mathrm{CH}_{3} \mathrm{NH}_{3} \mathrm{PbI}_{3}$ solar cells; two semitransparent and two opaque solar cells, comprising $\mathrm{CH}_{3} \mathrm{NH}_{3} \mathrm{PbI}_{3}$ layers with an $R_{\mathrm{rms}}$ of the $\mathrm{CH}_{3} \mathrm{NH}_{3} \mathrm{PbI}_{3}$ surface topography of either 10 or $50 \mathrm{~nm}$. We apply the scheme depicted in Figure 3 as an optical model to simulate the solar cells. Interface roughnesses are simulated using a BEMA layer consisting of a mixture of the optical constants of the adjacent media. The layer thicknesses used in the simulations of the $\mathrm{CH}_{3} \mathrm{NH}_{3} \mathrm{PbI}_{3}$ solar cells with $R_{\mathrm{rms}}$ of 10 and $50 \mathrm{~nm}$ are shown in Tables S1 and S2 (Supporting Information), respectively, along with the thicknesses measured by profilometry or targeted during evaporation. Figure 4 presents TMM-based simulations of reflectance, transmittance, and absorptance of the four solar cells, as well as the experimentally measured spectra. In order to quantify the agreement between simulations and experiment, we calculate the RMSE between simulated and experimental data. Table S3 (Supporting Information) lists the RMSE values for the four different solar cells, differentiated for wavelengths below and above the $\mathrm{CH}_{3} \mathrm{NH}_{3} \mathrm{PbI}_{3}$ bandgap wavelength of $800 \mathrm{~nm}$. We note that for all solar cells, the RMSE is higher for $\lambda>800 \mathrm{~nm}$, indicating a larger offset between experimental and simulated data for longer wavelengths. This is related to absorption in the substrate, which is higher for longer wavelengths but is not taken into account in the TMM-based simulations (Figure S11, Supporting Information). The differences between the RMSE values of the solar cells with different $R_{\mathrm{rms}}$ of the $\mathrm{CH}_{3} \mathrm{NH}_{3} \mathrm{PbI}_{3} /$ spiro-OMeTAD interface are small, indicating that the effect of diffuse scattering at this interface is limited. This is in sharp contrast to diffuse scattering at $\mathrm{CH}_{3} \mathrm{NH}_{3} \mathrm{PbI}_{3} /$ air interfaces, which may lead to increased parasitic absorption in the underlying layers, as explained in the previous section. The smaller difference in $n$ between $\mathrm{CH}_{3} \mathrm{NH}_{3} \mathrm{PbI}_{3}$ and spiro-OMeTAD as compared to $\mathrm{CH}_{3} \mathrm{NH}_{3} \mathrm{PbI}_{3}$ and air leads to a lower reflectivity at the $\mathrm{CH}_{3} \mathrm{NH}_{3} \mathrm{PbI}_{3}$ /spiro-OMeTAD interface. This explains why $\mathrm{CH}_{3} \mathrm{NH}_{3} \mathrm{PbI}_{3}$ surface roughness has a limited impact on the optical properties of full $\mathrm{CH}_{3} \mathrm{NH}_{3} \mathrm{PbI}_{3}$ solar cells but needs to be considered for single layers. In view of the application of semitransparent $\mathrm{CH}_{3} \mathrm{NH}_{3} \mathrm{PbI}_{3}$ solar cells in tandem architectures, this is an important step forward, as it shows that appropriate optical coupling can effectively reduce optical losses. At the same time, light scattering in multicrystalline perovskite (a)

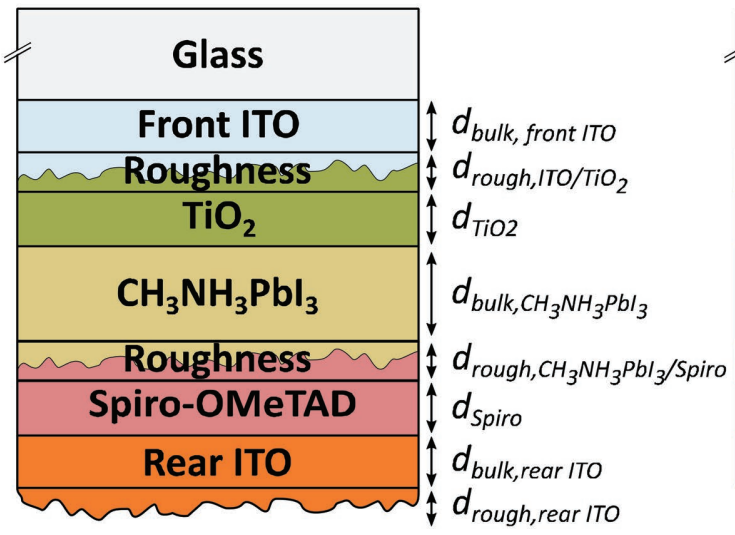

(b)

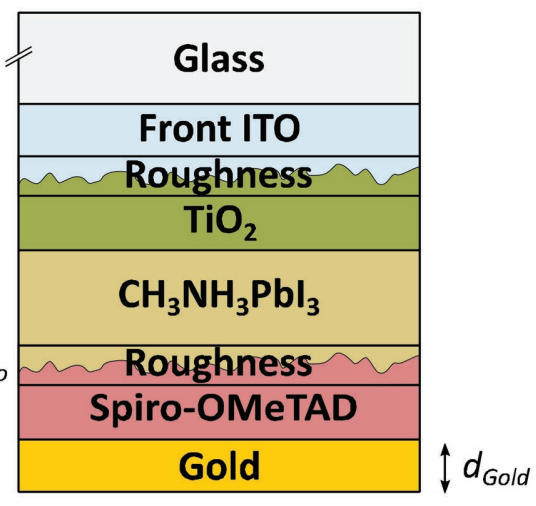

Figure 3. Solar cell architectures. Schematic model of a) the semitransparent and b) opaque $\mathrm{CH}_{3} \mathrm{NH}_{3} \mathrm{Pbl}_{3}$ solar cells applied for transfer-matrix-based optical simulations. Roughness is simulated as an effective medium of the adjacent media using the Bruggeman effective medium approximation. 

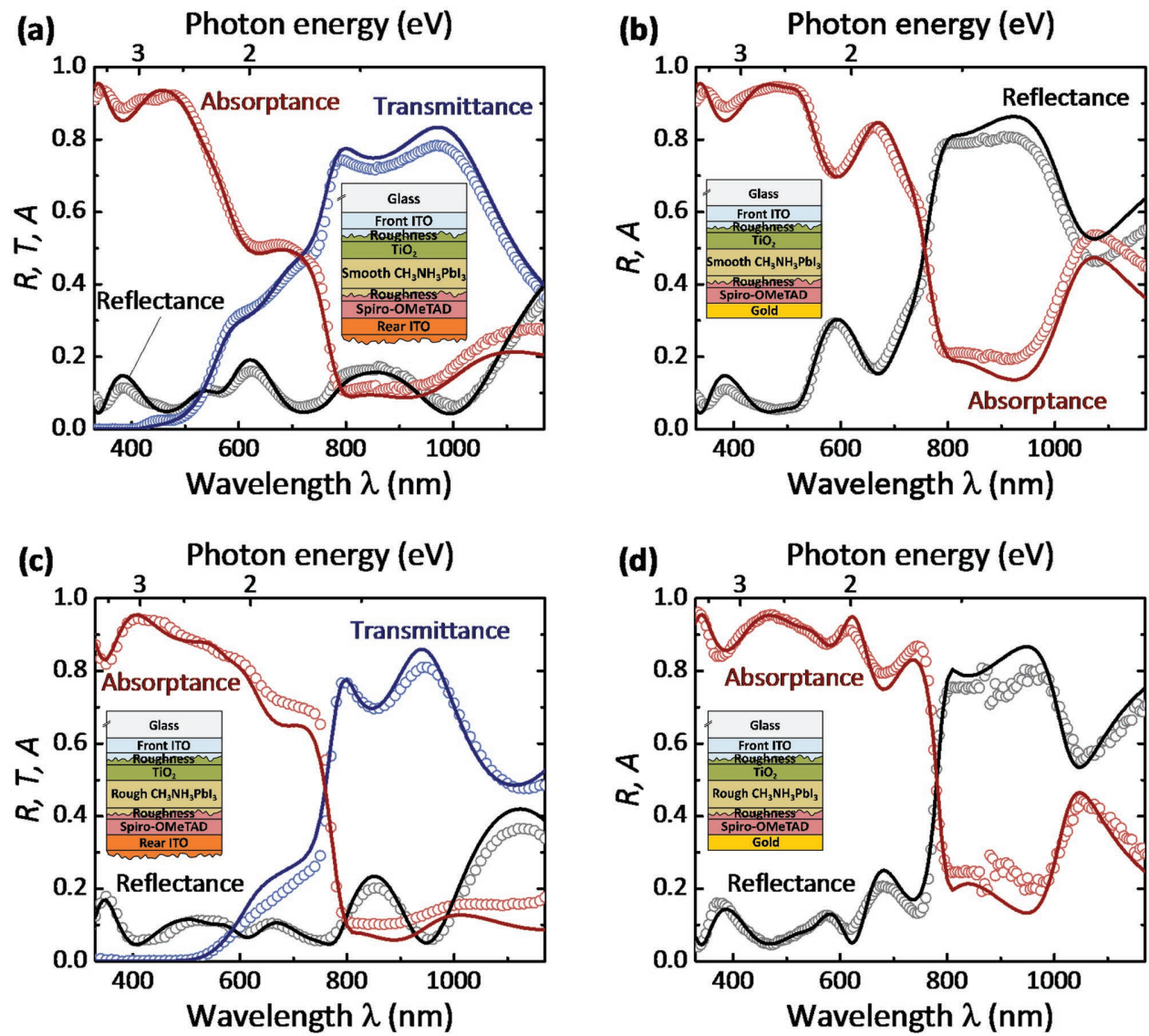

Figure 4. Reflectance, transmittance, and absorptance spectra of $\mathrm{CH}_{3} \mathrm{NH}_{3} \mathrm{Pbl}_{3}$ solar cells with the architecture substrate/ITO/TiO $/ \mathrm{CH}_{3} \mathrm{NH}_{3} \mathrm{Pbl} /$ spiro-OMeTAD/rear electrode, comprising $\mathrm{CH}_{3} \mathrm{NH}_{3} \mathrm{Pbl}_{3}$ films with different $R_{\mathrm{rms}}$ values of the multicrystalline $\mathrm{CH}_{3} \mathrm{NH}_{3} \mathrm{Pbl}_{3} / \mathrm{spiro}-\mathrm{OMeTAD}$ interface roughness. The symbols and lines represent measurements on actual devices and transfer-matrix-based simulations, respectively. a,c) Semitransparent solar cells comprising ITO as the rear electrode. b,d) Opaque solar cells comprising gold as rear electrode. $R_{\text {rms }}$ of the $\mathrm{CH}_{3} \mathrm{NH}_{3} \mathrm{Pbl}_{3} / \mathrm{spiro}-\mathrm{OMeTAD}$ interface roughness for the solar cells simulated in parts (a) and (b) is $10 \mathrm{~nm}$, whereas it is $50 \mathrm{~nm}$ for the solar cells simulated in parts (c) and (d).

solar cells can induce strong optical sub-bandgap absorption if the charge transport layers are very thin or exhibit a high contrast in refractive index to the perovskite layer.

\subsubsection{Partial Layer Stacks of Solar Cells}

To underline the accuracy of the obtained optical constants, we present TMM-based simulations of reflectance, transmittance, and absorptance of the partial layer stacks of the solar cells with an $R_{\mathrm{rms}}$ of $10 \mathrm{~nm}$ in Figure 5, along with the experimentally measured spectra. The layer thicknesses used in the simulations are equal to those used in the simulations of the full solar cells (Figure 4a,b), which are listed in Table S1 (Supporting Information). RMSE values quantifying the agreement between simulations and experiments are listed in Table S4 (Supporting Information). The offsets between experimental and simulated absorptance data for long wavelengths are again present and are explained by absorption in the substrate. The excellent agreement between simulations and experiment, exemplified by the low RMSE values of $\approx 0.02$, confirms the accuracy of the optical constants determined in this study.
The agreement between experimental and simulated optical data demonstrated for every $\mathrm{CH}_{3} \mathrm{NH}_{3} \mathrm{PbI}_{3}$ layer stack studied allows for the analysis and optimization through optical modeling of a wide range of device architectures, comprising $\mathrm{CH}_{3} \mathrm{NH}_{3} \mathrm{PbI}_{3}$ films deposited by different techniques. Hence, single-junction perovskite and multijunction perovskite/Si or perovskite/CIGS solar cells with optimal optical properties can be designed rationally. Having established the high accuracy and versatility of the provided data set, in the following section, we will demonstrate its potential in a detailed loss analysis.

\subsection{Loss Analysis}

In order to provide a direct comparison of the optical losses in a semitransparent and an opaque $\mathrm{CH}_{3} \mathrm{NH}_{3} \mathrm{PbI}_{3}$ solar cell, we simulate both solar cells using identical layers and layer thicknesses, with the exception of the rear electrode. The thicknesses used in the simulations of both the semitransparent and opaque solar cells are equal to those listed for the semitransparent solar cell in Table S2 (Supporting Information), but the opaque solar cell employs a $100 \mathrm{~nm}$ Au rear electrode instead of an ITO rear electrode. The total reflectance, total 

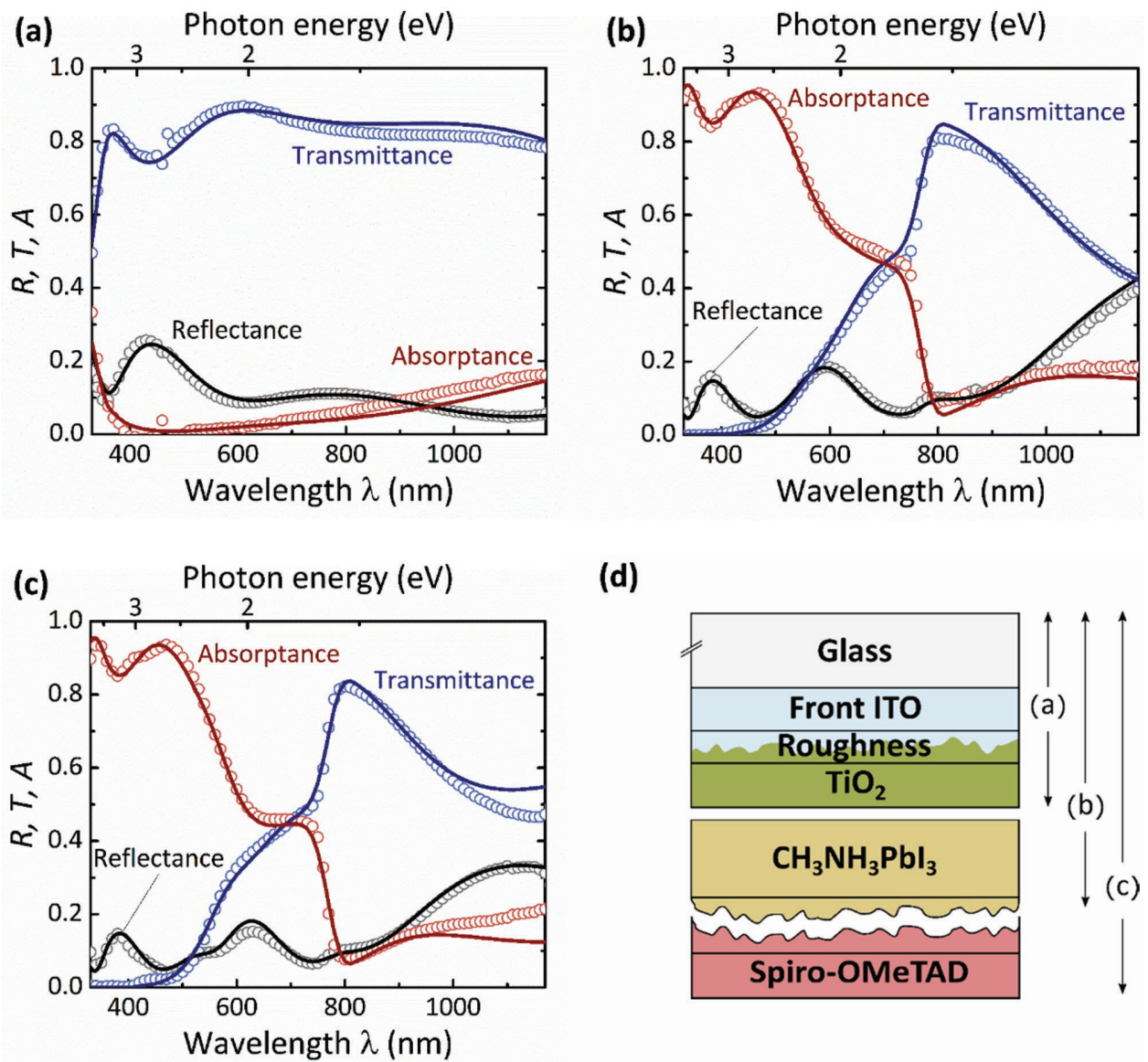

(d)

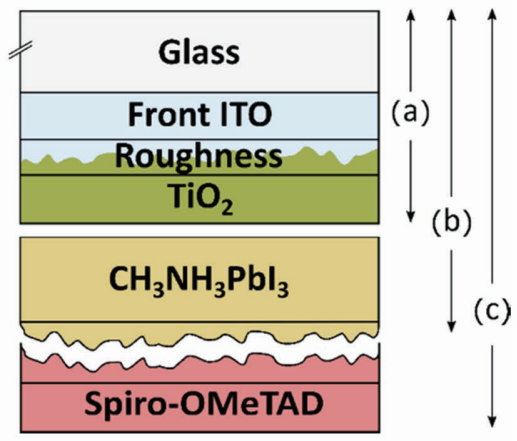

Figure 5. Reflectance, transmittance, and absorptance spectra of the partial layer stacks in the $\mathrm{CH}_{3} \mathrm{NH}_{3} \mathrm{Pbl}$ solar cell architecture studied. The symbols and lines indicate measurements and transfer-matrix-based simulations, respectively. a-c) Spectra of the partial layer stacks indicated in part (d). $R_{\mathrm{rms}}$ of the surface topography of $\mathrm{CH}_{3} \mathrm{NH}_{3} \mathrm{Pbl}_{3}$ in the layer stacks in parts (b) and (c) is $10 \mathrm{~nm}$.

transmittance, and absorptance in each layer of the semitransparent and opaque solar cells are shown in Figure $6 a, b$, respectively. Using AM1.5G solar irradiance and assuming an internal quantum efficiency of unity, the optical losses are discriminated for all layers and reflection losses, by representing them by the corresponding loss in short-circuit photocurrent density $\left(U_{\mathrm{SC}}\right)$ in Table 1 . Most notably, the semitransparent solar cell exhibits a significant transmission $\left(4.9 \mathrm{~mA} \mathrm{~cm}{ }^{-2}\right)$ due to incomplete absorption of near-bandgap photons. The gold rear mirror of the opaque solar cell reflects most of these photons back into the cell, increasing the absorption in $\mathrm{CH}_{3} \mathrm{NH}_{3} \mathrm{PbI}_{3}$ by $2.6 \mathrm{~mA} \mathrm{~cm}{ }^{-2}$. Of highest importance for both
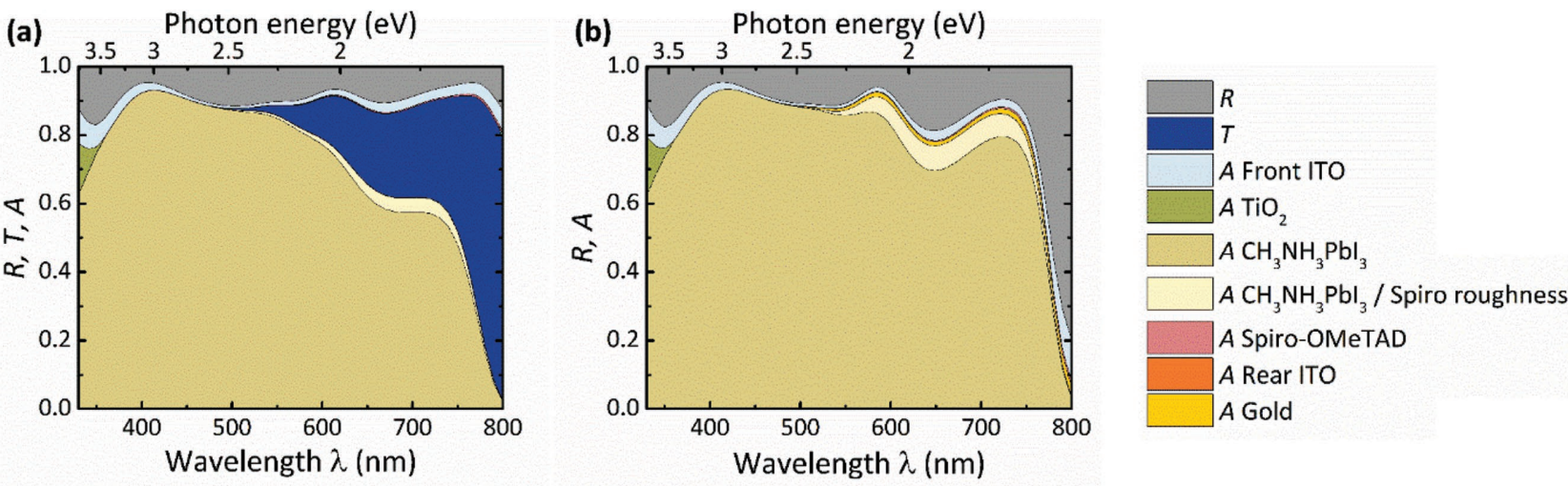

Figure 6. Optical analysis of semitransparent and opaque $\mathrm{CH}_{3} \mathrm{NH}_{3} \mathrm{Pbl}_{3}$ solar cells. a) Reflectance, transmittance, and absorptance in each individual layer of the semitransparent solar cell, as simulated in Figure 4c. b) Reflectance and absorptance in each individual layer of the opaque solar cell, simulated with layer thicknesses analogues to the semitransparent solar cell, except with $100 \mathrm{~nm}$ gold instead of the rear ITO. 
Table 1. Optical analysis of the semitransparent and opaque $\mathrm{CH}_{3} \mathrm{NH}_{3} \mathrm{Pbl}_{3}$ solar cells, showing the potential photocurrent density (U) attributable to the different processes obtained by integration assuming AM1.5G solar irradiance. For the optical analysis, a wavelength range of 330-800 nm (the bandgap wavelength of $\mathrm{CH}_{3} \mathrm{NH}_{3} \mathrm{Pbl}_{3}$ ) was considered.

\begin{tabular}{lcc}
\hline Process & \multicolumn{2}{c}{$J\left[\mathrm{~mA} \mathrm{~cm}^{-2}\right]$} \\
\cline { 2 - 3 } & Semitransparent & Opaque \\
\hline Total reflection & 2.3 & 4.2 \\
Total transmission & 4.9 & 0.0 \\
Absorption in $\mathrm{TiO}_{2}$ & 0.0 & 0.0 \\
Absorption in front ITO & 0.6 & 0.7 \\
Absorption in $\mathrm{CH}_{3} \mathrm{NH}_{3} \mathrm{Pbl}_{3}$ & 18.5 & 20.6 \\
Absorption in $\mathrm{CH}_{3} \mathrm{NH}_{3} \mathrm{Pbl}_{3} /$ Spiro-OMeTAD & 0.5 & 1.0 \\
roughness layer & & \\
Absorption in Spiro-OMeTAD & 0.1 & 0.1 \\
Absorption in rear ITO & 0.0 & - \\
Absorption in gold & - & 0.3 \\
Total & 26.9 & 26.9 \\
\hline
\end{tabular}

a) In the main text, this photocurrent is attributed to absorption in $\mathrm{CH}_{3} \mathrm{NH}_{3} \mathrm{Pbl}_{3}$, since for energies above the $\mathrm{CH}_{3} \mathrm{NH}_{3} \mathrm{Pbl}_{3}$ bandgap energy, it holds that $k_{\mathrm{CH} 3 \mathrm{NH} 3 \mathrm{PbI}}$ $\gg k_{\text {spiro-OMeTAD }}$

solar cell architectures is imperfect light incoupling and reflection. The gold rear mirror causes this loss to be larger for the opaque cell $\left(4.2 \mathrm{~mA} \mathrm{~cm}^{-2}\right)$ compared to the semitransparent cell $\left(2.3 \mathrm{~mA} \mathrm{~cm}^{-2}\right)$. Absorption in the front TCOs, mainly in the $\mathrm{UV}$, causes less photons to reach the photoactive $\mathrm{CH}_{3} \mathrm{NH}_{3} \mathrm{PbI}_{3}$ layer in both the semitransparent cell $\left(0.6 \mathrm{~mA} \mathrm{~cm}{ }^{-2}\right)$ and the opaque cell $\left(0.7 \mathrm{~mA} \mathrm{~cm}^{-2}\right)$. In both architectures, the parasitic absorption losses in the charge transport layers and rear electrode combined are limited to less than $0.5 \mathrm{~mA} \mathrm{~cm}^{-2}$. We use TMM-based simulations to simulate the effect of front-side single-layer antireflection coatings (ARCs) with $n=1.25$ and different thicknesses, addressing the impact of imperfect light incoupling. For an optimal thickness of $125 \mathrm{~nm}$, the reflection decreases by 0.9 and $0.8 \mathrm{~mA} \mathrm{~cm}^{-2}$ for the semitransparent and the opaque solar cell, respectively. This may lead directly to improved device performance due to increases in the achievable $J_{\mathrm{SC}}$ in the semitransparent $\left(0.7 \mathrm{~mA} \mathrm{~cm}^{-2}\right)$ and opaque $\left(0.8 \mathrm{~mA} \mathrm{~cm}^{-2}\right)$ solar cell. To further reduce the losses due to imperfect light incoupling, advanced light management strategies such as nanophotonic front electrodes can be employed. ${ }^{[35]}$

The optical data determined in this study can be further explored to investigate $\mathrm{CH}_{3} \mathrm{NH}_{3} \mathrm{PbI}_{3} / \mathrm{c}-\mathrm{Si}$ tandem solar cells. In Figure 7 the optical analysis of a four-terminal $\mathrm{CH}_{3} \mathrm{NH}_{3} \mathrm{PbI}_{3} / \mathrm{c}$-Si tandem solar cell comprising the semitransparent $\mathrm{CH}_{3} \mathrm{NH}_{3} \mathrm{PbI}_{3}$ solar cell studied in this work as top cell and an in-house developed interdigitated back contact (IBC) c-Si bottom cell is shown. The external quantum efficiency (EQE) of the IBC c-Si bottom cell was calculated by multiplying the transmittance of the semitransparent $\mathrm{CH}_{3} \mathrm{NH}_{3} \mathrm{PbI}_{3}$ top cell with the EQE spectrum of the bare IBC c-Si solar cell (see Figure S13 of the Supporting Information). Table 2 discriminates the optical losses for all layers as well as reflection losses and represents them by the corresponding loss in short-circuit photocurrent density, assuming AM1.5G solar irradiance and an IQE of unity. Since the optical losses of the c-Si bottom solar cell and the perovskite top cell are mostly concerned with different spectral regions, we discriminate them at the $\mathrm{CH}_{3} \mathrm{NH}_{3} \mathrm{PbI}_{3}$ bandgap. A similar four-terminal perovskite/c-Si solar cell was prototyped in a previous work by Jaysankar et al. ${ }^{[23]}$ Of paramount importance for tandem applications is the light in- and outcoupling of the semitransparent top cell for wavelengths longer than the bandgap wavelength. In this wavelength range $(\lambda>800 \mathrm{~nm})$, reflection accounts for a loss of $4.1 \mathrm{~mA} \mathrm{~cm}{ }^{-2}$. This loss can be addressed by incorporating ARCs at both the front and the rear side of the semitransparent $\mathrm{CH}_{3} \mathrm{NH}_{3} \mathrm{PbI}_{3}$ solar cell. The optimal characteristics of a rear-side ARC depend largely on the optical properties of the semitransparent rear electrode. For the sputtered ITO studied in this work, using TMM-based simulations we calculate that a $125 \mathrm{~nm}$ thick, single-layer rear ARC with $n \approx 1.5$ increases the $J_{\mathrm{SC}}$ in the IBC c-Si bottom cell by $1.6 \mathrm{~mA} \mathrm{~cm}^{-2}$. However, simultaneously, the absorption in $\mathrm{CH}_{3} \mathrm{NH}_{3} \mathrm{PbI}_{3}$ decreases by $0.4 \mathrm{~mA} \mathrm{~cm}^{-2}$ due to decreased back reflection. By employing the optimized ARCs at the front- and rear-sides of the semitransparent solar cell simultaneously, we calculate the increases in the absorption in $\mathrm{CH}_{3} \mathrm{NH}_{3} \mathrm{PbI}_{3}$ and $J_{\mathrm{SC}}$ in the IBC c-Si bottom cell to be 0.4 and $2.1 \mathrm{~mA} \mathrm{~cm}^{-2}$, respectively. In addition to reflection losses, free carrier absorption in TCOs is a well-known parasitic loss mechanism, preventing photons from reaching the bottom cell in multijunction solar cells. In the studied four-terminal tandem architecture, a potential $J_{\mathrm{SC}}$ of $1.3 \mathrm{~mA} \mathrm{~cm}^{-2}$ is lost to parasitic absorption in the front and rear ITO combined. Novel high-mobility TCOs like hydrogenated indium oxide (IO:H) exhibit lower free carrier densities than the commonly used ITO, thereby offering the potential to reduce the long-wavelength parasitic absorption. ${ }^{[22,63]}$ Recently, almost complete elimination of the long-wavelength parasitic losses

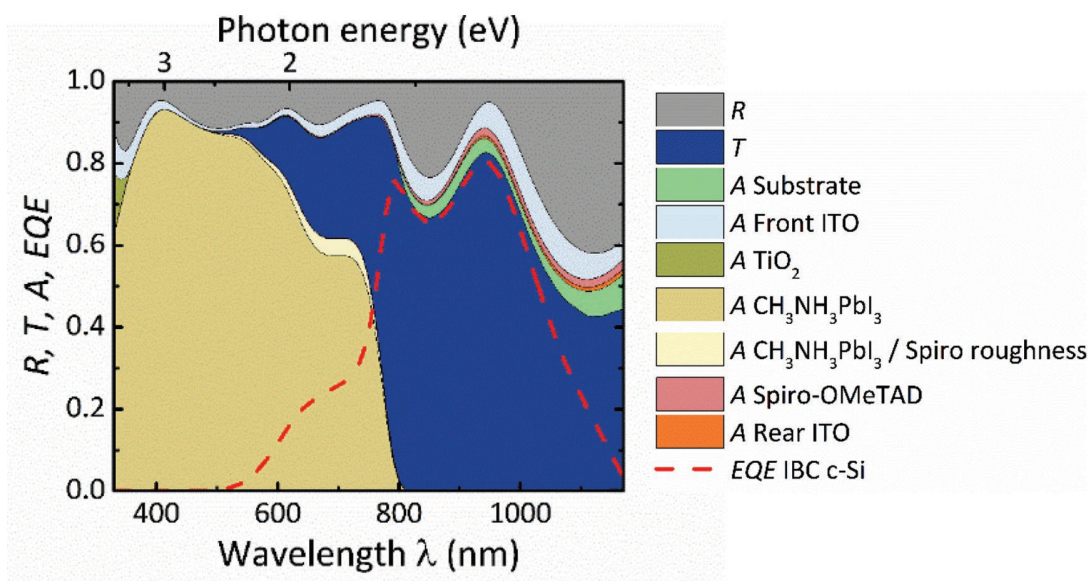

Figure 7. Optical analysis of a four-terminal tandem architecture comprising a semitransparent $\mathrm{CH}_{3} \mathrm{NH}_{3} \mathrm{Pbl}_{3}$ top cell and an IBC c-Si bottom cell. The EQE of the IBC c-Si bottom cell was calculated by multiplying the transmittance of the semitransparent $\mathrm{CH}_{3} \mathrm{NH}_{3} \mathrm{Pbl}_{3}$ top cell by the $\mathrm{EQE}$ of the bare IBC c-Si solar cell. 
Table 2. Optical analysis of the four-terminal $\mathrm{CH}_{3} \mathrm{NH}_{3} \mathrm{Pbl}_{3} / \mathrm{IBC}$ c-S tandem solar cell, showing the potential photocurrent density $(J)$ attributable to the different processes, obtained by integration assuming AM1.5G solar irradiance. For the optical analysis a wavelength range of $800-1170 \mathrm{~nm}$ (the bandgap wavelength of Si) was considered, except where noted otherwise.

\begin{tabular}{lc}
\hline Process & $\begin{array}{c}J \\
{\left[\mathrm{~mA} \mathrm{~cm}^{-2}\right]}\end{array}$ \\
\hline Total reflection & 4.1 \\
Transmission $(\lambda<800 \mathrm{~nm})$ & 4.9 \\
Transmission $(\lambda>800 \mathrm{~nm})$ & 11.5 \\
Absorption in TiO 2 & 0.0 \\
Absorption in front ITO & 1.2 \\
Absorption in Spiro-OMeTAD & 0.3 \\
Absorption in rear ITO & 0.1 \\
Absorption in substrate $)$ & 0.6 \\
Total $(\lambda>800 \mathrm{~nm})$ & 17.8 \\
EQE IBC c-Si $(\lambda<800 \mathrm{~nm})$ & 4.8 \\
EQE IBC c-Si $(\lambda>800 \mathrm{~nm})$ & 10.2 \\
\hline
\end{tabular}

a) The absorption in the substrate is estimated by computing the difference between measured and simulated absorptance of the semitransparent solar cell.

in the TCO was demonstrated by replacing ITO with IO:H. ${ }^{[63]}$ Simultaneously, the parasitic losses in the UV also decreased due to decreased band-to-band absorption in IO:H compared to ITO. We therefore estimate that replacing both our ITOs with IO: $\mathrm{H}$ can result in an increase of $0.3 \mathrm{~mA} \mathrm{~cm} \mathrm{~cm}^{-2}$ of absorption in $\mathrm{CH}_{3} \mathrm{NH}_{3} \mathrm{PbI}_{3}$ and increase the $J_{\mathrm{SC}}$ in the IBC c-Si bottom cell by $\approx 1 \mathrm{~mA} \mathrm{~cm}^{-2}$, neglecting the effect of the different $n$ of IO:H compared to ITO. The parasitic absorption losses in the charge transport layers and rear electrode combined are limited $\left(0.3 \mathrm{~mA} \mathrm{~cm}^{-2}\right)$. Parasitic losses due to absorption in the substrate and diffuse scattering $\left.(\approx 0.6 \mathrm{~mA} \mathrm{~cm})^{-2}\right)$ can be completely mitigated by the use of ultrasmooth $\mathrm{CH}_{3} \mathrm{NH}_{3} \mathrm{PbI}_{3}$ films and nonabsorbing substrates. The $J_{\mathrm{SC}}$ value obtained by integrating the EQE spectrum of the IBC c-Si bottom cell of $15.0 \mathrm{~mA} \mathrm{~cm}^{-2}$ is in fair agreement with the experimentally measured $J_{\mathrm{SC}}$ of $15.2 \mathrm{~mA} \mathrm{~cm} \mathrm{~cm}^{-2}$ of this IBC c-Si bottom cell in a four-terminal configuration. Similarly, the simulated absorption in $\mathrm{CH}_{3} \mathrm{NH}_{3} \mathrm{PbI}_{3}$ of $19.0 \mathrm{~mA} \mathrm{~cm}{ }^{-2}$ is in agreement with an experimentally measured $J_{\mathrm{SC}}$ of $18.2 \mathrm{~mA} \mathrm{~cm}^{-2}$ of the semitransparent $\mathrm{CH}_{3} \mathrm{NH}_{3} \mathrm{PbI}_{3}$ solar cell. ${ }^{[23]}$ It should be noted that transmitted photons below the $\mathrm{CH}_{3} \mathrm{NH}_{3} \mathrm{PbI}_{3}$ bandgap wavelength represent a loss in overall energy yield of the four-terminal tandem solar cell, even though they contribute almost fully to current generation in the IBC c-Si bottom cell, because of the higher $V_{\mathrm{OC}}$ of the semitransparent top cell. Optimization of the semitransparent $\mathrm{CH}_{3} \mathrm{NH}_{3} \mathrm{PbI}_{3}$ top cell to maximize absorption for $\lambda<800 \mathrm{~nm}$ can therefore contribute to increasing the overall energy yield of the four-terminal architecture. ${ }^{[18]}$ An alternative route is the use of intermediate reflectors to improve spectral light management as demonstrated in the past in, for example, tandem thin-film silicon solar cells. ${ }^{[64]}$

The incorporation of the above-discussed and well-known optical concepts to improve light harvesting in solar cells, in conjunction with the complete mitigation of the parasitic absorption losses in the charge transport layers, may already lead to a total increase of $0.8 \mathrm{~mA} \mathrm{~cm}{ }^{-2}$ of absorption in $\mathrm{CH}_{3} \mathrm{NH}_{3} \mathrm{PbI}_{3}$ and increase the $J_{\mathrm{SC}}$ of the IBC c-Si bottom cell by $3.8 \mathrm{~mA} \mathrm{~cm}^{-2}$. This translates to maximum attainable relative increases in $J_{\mathrm{SC}}$ of $4 \%$ and $25 \%$ for the semitransparent $\mathrm{CH}_{3} \mathrm{NH}_{3} \mathrm{PbI}_{3}$ top cell and the IBC c-Si bottom cell, respectively, leading to a $13 \%$ relative increase in the overall power conversion efficiency of the four-terminal perovskite/Si solar cell, only based on optimizing the optics in the studied $\mathrm{CH}_{3} \mathrm{NH}_{3} \mathrm{PbI}_{3}$ layer stack with well-established optical concepts for light harvesting in solar cells. More advanced light management concepts, trapping textures, and the optimization of the bandgap of the perovskite bear the potential to lead to very significant further improvements in light harvesting and current generation. ${ }^{[18]}$ Overall, we demonstrated that the optical data provided in this work enable for the optical optimization of single- and multijunction perovskite solar cells.

\section{Conclusion}

In this study, we have shown a rigorous optical analysis of semitransparent and opaque planar $\mathrm{CH}_{3} \mathrm{NH}_{3} \mathrm{PbI}_{3}$ solar cells. Optical constants of the relevant device materials were determined by simultaneously fitting variable-angle spectroscopic ellipsometry and spectrophotometry data. Transfer-matrixbased optical simulations of partial and complete solar cells showed excellent agreement to experimental data. The impact of roughness of the $\mathrm{CH}_{3} \mathrm{NH}_{3} \mathrm{PbI}_{3}$ surface topography on the optical properties of $\mathrm{CH}_{3} \mathrm{NH}_{3} \mathrm{PbI}_{3}$ layer stacks was shown to be severe but only minor in full solar cells. A ray-tracing model was developed, which is able to account for the experimentally observed sub-bandgap absorption in $\mathrm{CH}_{3} \mathrm{NH}_{3} \mathrm{PbI}_{3}$ layer stacks, which primarily takes place in the substrate. We have directly compared the optical losses present in semitransparent and opaque planar $\mathrm{CH}_{3} \mathrm{NH}_{3} \mathrm{PbI}_{3}$ solar cells. In addition, the optical losses of an experimentally demonstrated four-terminal perovskite/Si tandem device were analyzed in detail and the areas in which optical improvements can lead to increased tandem performance were highlighted. Our work enables careful optical design and optimization of a wide variety of single- and multijunction perovskite solar cells. We believe this will prove crucial to progress the perovskite photovoltaic technology to a level that either rivals or complements the well-established, commercially available technologies such as Si photovoltaics.

\section{Experimental Section}

Sample Preparation: ITO-coated glass substrates with a sheet resistance $\left(R_{\text {sheet }}\right)$ of $\approx 15 \Omega^{-1}$ were purchased from Colorado Concept Coatings LLC. Both the semitransparent and opaque $\mathrm{CH}_{3} \mathrm{NH}_{3} \mathrm{Pbl}_{3}$ $\left(R_{\text {rms }}: 10 \mathrm{~nm}\right)$ solar cells as well as the opaque $\mathrm{CH}_{3} \mathrm{NH}_{3} \mathrm{Pbl}_{3}\left(R_{\mathrm{rms}}\right.$ : $50 \mathrm{~nm}$ ) solar cells were prepared on these substrates. In the case of the semitransparent and opaque $\mathrm{CH}_{3} \mathrm{NH}_{3} \mathrm{Pbl}_{3}\left(\mathrm{R}_{\mathrm{rms}}: 10 \mathrm{~nm}\right)$ cells, a single substrate was used, on which first films of $\mathrm{TiO}_{2}, \mathrm{CH}_{3} \mathrm{NH}_{3} \mathrm{Pbl}_{3}$, and spiro-OMeTAD were deposited, after which one half was coated with gold and the other half with ITO through appropriate shadow masks by thermal evaporation and sputtering, respectively. The Colorado Concept Coatings ITO-patterned glass substrates were also used as glass substrates for the optical characterization of the individual 
material layers. The semitransparent $\mathrm{CH}_{3} \mathrm{NH}_{3} \mathrm{Pbl}_{3}\left(R_{\mathrm{rms}}: 50 \mathrm{~nm}\right)$ solar cells were fabricated on ITO-coated glass substrates $\left(R_{\text {sheet }} \approx 25 \Omega \square^{-1}\right)$, which were purchased from Thin Film Devices, Inc. All ITO-coated glass substrates and $\mathrm{Si} / \mathrm{SiO}_{2}$ substrates were cleaned prior to film deposition by rubbing with soap solution and subsequently sonicating in baths of soap, deionized water, acetone, and isopropanol for $5 \mathrm{~min}$ each. $\mathrm{TiO}_{2}$ films were evaporated at a rate of $\approx 1 \AA \mathrm{As}^{-1}$ under a partial $\mathrm{O}_{2}$ pressure of $1.7 \times 10^{-4}$ Torr using an Angstrom Engineering e-beam evaporation system. The rear ITO was sputtered in-house by DC magnetron sputtering at argon pressures of $\approx 0.3 \mathrm{mTorr}$ from an indium-tin-oxide source at an $\mathrm{O}_{2}$ flow rate of $6 \mathrm{sscm}$ using a NEXX Systems Nimbus 310 setup. To deposit Spiro-OMeTAD onto $\mathrm{CH}_{3} \mathrm{NH}_{3} \mathrm{Pbl}_{3}$, a solution of spiro-OMeTAD ( $80 \mathrm{mg}, 0.065 \mathrm{mmol}$ ), purchased from Sigma-Aldrich, in chlorobenzene $(1 \mathrm{~mL})$, doped with lithium bis(trifluoromethanesulfonyl)imide $\left(17.5 \mu \mathrm{L}\right.$ of a $520 \mathrm{mg} \mathrm{mL}^{-1}$ solution in acetonitrile) and 4-tertbutylpyridine $(28.5 \mu \mathrm{L})$, was spin-coated for $60 \mathrm{~s}$ at $2000 \mathrm{rpm}$ using an acceleration of $5000 \mathrm{rpm} \mathrm{s}^{-1}$. This study experienced practical issues related to the wetting of this spiro-OMeTAD solution on glass and $\mathrm{Si} /$ $\mathrm{SiO}_{2}$ substrates to prepare the single layers of spiro-OMeTAD used in the optical characterization. Therefore, these samples were produced from a solution with toluene as a solvent, and a spin-coating acceleration of $500 \mathrm{rpm} \mathrm{s}^{-1}$ was used. In both cases, the films were then stored under $\approx 20 \%$ relative humidity to expose them to oxygen which facilitates the doping of spiro-OMeTAD. ${ }^{[57,65]} \mathrm{CH}_{3} \mathrm{NH}_{3} \mathrm{Pbl}_{3}$ films with an $R_{\mathrm{rms}}$ of $50 \mathrm{~nm}$ were prepared from a precursor solution of $\mathrm{CH}_{3} \mathrm{NH}_{3} \mathrm{I}$ (Dyesol), $\mathrm{PbCl}_{2}$ (Sigma-Aldrich), and $\mathrm{Pb}\left(\mathrm{CH}_{3} \mathrm{CO}_{2}\right)_{2} \cdot 3 \mathrm{H}_{2} \mathrm{O}$ (Sigma-Aldrich) in $\mathrm{N}, \mathrm{N}$ dimethylformamide. The total lead concentration was $0.8 \mathrm{~m}$, while the total $\mathrm{CH}_{3} \mathrm{NH}_{3}$ I concentration was $2.4 \mathrm{M}$. The ratio of $\mathrm{Pb}\left(\mathrm{CH}_{3} \mathrm{CO}_{2}\right)_{2} \cdot 3 \mathrm{H}_{2} \mathrm{O}$ to $\mathrm{PbCl}_{2}$ was 2:1. The solution was spin-coated at $3000 \mathrm{rpm}$ using an acceleration of $5000 \mathrm{rpm} \mathrm{s}^{-1}$ and subsequently annealed by ramping the temperature in $5 \mathrm{~min}$ from $90^{\circ}$ to $130^{\circ}$ and maintaining at $130^{\circ}$ for $10 \mathrm{~min}$. This recipe, optimized for large-area uniform and pinhole-free film deposition, ${ }^{[36]}$ typically yields $\approx 300 \mathrm{~nm}$ thick films. $\mathrm{CH}_{3} \mathrm{NH}_{3} \mathrm{Pbl}_{3}$ films with an $R_{\mathrm{rms}}$ of $10 \mathrm{~nm}$ were prepared from a precursor solution of $\mathrm{Pbl}_{2}(461 \mathrm{mg}, 1 \mathrm{mmol})$ and $\mathrm{CH}_{3} \mathrm{NH}_{3} \mathrm{I}(159 \mathrm{mg}, 1 \mathrm{mmol})$ in a solvent mixture of $\gamma$-butyrolacton $(0.7 \mathrm{~mL})$ and dimethylsulfoxide $(0.3 \mathrm{~mL})$. The solution was stirred at room temperature for at least $1 \mathrm{~h}$ prior to spincoating it at $4000 \mathrm{rpm}$ for $45 \mathrm{~s}$ using an acceleration of $4000 \mathrm{rpm} \mathrm{s}^{-1}$. After $20 \mathrm{~s}$ of spin-coating, toluene $(80 \mu \mathrm{L})$ was dripped onto the films. The films were subsequently annealed at $100^{\circ}$ for $10 \mathrm{~min}$. This recipe is optimized to produce smooth films and typically yields $\approx 150 \mathrm{~nm}$ thick films. Opaque solar cells were completed by thermally evaporating a gold rear electrode using an Amod Angstrom system.

Sample Characterization and Data Analysis: Two different spectrophotometric setups were used to acquire near-normal incidence reflectance and transmittance data (for details, see the Supporting Information). Setup 1 comprised a Perkin Elmer Lambda 950 UV/Vis Spectrometer. Setup 2 consisted of a Bentham PVE300 spectral response system comprising an integrating sphere that allows for separate measurements of diffuse and total reflectance or transmittance. Variableangle spectroscopic ellipsometry spectra were recorded under ambient conditions using a Sopra GES-5 rotating polarizer ellipsometer. The ellipsometric data were analyzed using Spectroscopic Ellipsometry Analyzer software. An in-house developed code based on the transfer-matrix method was used to simulate reflectance, transmittance, and absorptance spectra. Film thicknesses and surface roughnesses were determined using a Veeco Dektak profilometer and atomic force microscopy.

\section{Supporting Information}

Supporting Information is available from the Wiley Online Library or from the author.

\section{Acknowledgements}

This research had received (partial) funding from the Flemish Government-Department of Economics, Science and Innovation.
The authors acknowledge the Initiating and Networking funding of the Helmholtz Association (HYIG of U. Paetzold), the KIT Young Investigator Network, and the Karlsruhe School of Optics \& Photonics (KSOP). Furthermore, financial support from the Honours Beyond the Frontiers program of the Radboud University Nijmegen is acknowledged. The authors thank D. Cheyns, G. Uytterhoeven, and J. G. Tait for technical support and M. Smeets and K. Bittkau from Forzungszentrum Jülich for kindly providing the opportunity to collect spectrophotometry data at their institute.

\section{Conflict of Interest}

The authors declare no conflict of interest.

\section{Keywords}

ellipsometry, optical data, perovskite solar cells, refractive index, surface roughness

Received: February 16, 2017

Revised: April 24, 2017

Published online:

[1] A. Kojima, K. Teshima, Y. Shirai, T. Miyasaka, J. Am. Chem. Soc. 2009, 131, 6050 .

[2] M. A. Contreras, L. M. Mansfield, B. Egaas, J. Li, M. Romero, R. Noufi, E. Rudiger-voigt, W. Mannstadt, Prog. Photovoltaics 2007, $15,659$.

[3] D. P. McMeekin, G. Sadoughi, W. Rehman, G. E. Eperon, M. Saliba, M. T. Horantner, A. Haghighirad, N. Sakai, L. Korte, B. Rech, M. B. Johnston, L. M. Herz, H. J. Snaith, Science 2016, 351, 151.

[4] D. Bi, W. Tress, M. I. Dar, P. Gao, J. Luo, C. Renevier, K. Schenk, A. Abate, F. Giordano, J.-P. Correa Baena, J.-D. Decoppet, S. M. Zakeeruddin, M. K. Nazeeruddin, M. Grätzel, A. Hagfeldt, Sci. Adv. 2016, 2, e1501170.

[5] M. Saliba, T. Matsui, J.-Y. Seo, K. Domanski, J.-P. Correa-Baena, M. K. Nazeeruddin, S. M. Zakeeruddin, W. Tress, A. Abate, A. Hagfeldt, M. Grätzel, Energy Environ. Sci. 2016, 9, 1989.

[6] J. T. Jacobsson, J. P. Correa Baena, M. Pazoki, M. Saliba, K. Schenk, M. Grätzel, A. Hagfeldt, Energy Environ. Sci. 2016, 41, 1.

[7] U.-G. Jong, C.-J. Yu, J.-S. Ri, N.-H. Kim, G.-C. Ri, Phys. Rev. B 2016, 94, 125139.

[8] J. H. Noh, S. H. Im, J. H. Heo, T. N. Mandal, S. II Seok, Nano Lett. 2013, 13, 1764

[9] S. A. Kulkarni, T. Baikie, P. P. Boix, N. Yantara, N. Mathews, S. Mhaisalkar, J. Mater. Chem. A 2014, 2, 9221.

[10] M. Jaysankar, W. Qiu, J. P. Bastos, J. G. Tait, M. Debucquoy, U. W. Paetzold, D. Cheyns, J. Poortmans, J. Mater. Chem. A 2016, 4, 10524.

[11] M. Grätzel, Nat. Mater. 2014, 13, 838

[12] S. De Wolf, J. Holovsky, S. J. Moon, P. Löper, B. Niesen, M. Ledinsky, F. J. Haug, J. H. Yum, C. Ballif, J. Phys. Chem. Lett. 2014, 5, 1035

[13] P. Löper, M. Stuckelberger, B. Niesen, J. Werner, M. Filipic, S.-J. Moon, J.-H. Yum, M. Topic, S. De Wolf, C. Ballif, J. Phys. Chem. Lett. 2015, 6, 66 .

[14] G. Xing, N. Mathews, S. S. Lim, Y. M. Lam, S. Mhaisalkar, T. C. Sum, Science 2013, 6960, 498.

[15] S. D. Stranks, G. E. Eperon, G. Grancini, C. Menelaou, M. J. P. Alcocer, T. Leijtens, L. M. Herz, A. Petrozza, H. J. Snaith, Science 2014, 342, 341. 
[16] H. J. Snaith, J. Phys. Chem. Lett 2013, 4, 3623.

[17] W. Shockley, H. J. Queisser, J. Appl. Phys. 1961, 32, 510.

[18] N. N. Lal, T. P. White, K. R. Catchpole, IEEE J. Photovoltaics 2014, 4, 1380.

[19] P. Löper, B. Niesen, S.-J. Moon, S. Martin de Nicolas, J. Holovsky, Z. Remes, M. Ledinsky, F.-J. Haug, J.-H. Yum, S. De Wolf, C. Ballif, IEEE J. Photovoltaics 2014, 4, 1545.

[20] B. Chen, Y. Bai, Z. Yu, T. Li, X. Zheng, Q. Dong, L. Shen, M. Boccard, A. Gruverman, Z. Holman, J. Huang, Adv. Energy Mater. 2016, 6, 1.

[21] J. Werner, L. Barraud, A. Walter, M. Bräuninger, F. Sahli, D. Sacchetto, N. Tétreault, B. Paviet-Salomon, S.-J. Moon, C. Allebé, M. Despeisse, S. Nicolay, S. De Wolf, B. Niesen, C. Ballif, ACS Energy Lett. 2016, 1, 474.

[22] F. Fu, T. Feurer, T. Jäger, E. Avancini, B. Bissig, S. Yoon, S. Buecheler, A. N. Tiwari, Nat. Commun. 2015, 6, 8932

[23] M. Jaysankar, W. Qiu, M. van Eerden, T. Aernouts, R. Gehlhaar, M. Debucquoy, U. W. Paetzold, J. Poortmans, Adv. Energy Mater. 2017, 7, 1602807.

[24] K. A. Bush, A. F. Palmstrom, Z. J. Yu, M. Boccard, R. Cheacharoen, J. P. Mailoa, D. P. McMeekin, R. L. Z. Hoye, C. D. Bailie, T. Leijtens, I. M. Peters, M. C. Minichetti, N. Rolston, R. Prasanna, S. Sofia, D. Harwood, W. Ma, F. Moghadam, H. J. Snaith, T. Buonassisi, Z. C. Holman, S. F. Bent, M. D. McGehee, Nat. Energy 2017, 2, 17009.

[25] T. Duong, Y. Wu, H. Shen, J. Peng, X. Fu, D. Jacobs, E. Wang, T. C. Kho, K. C. Fong, M. Stocks, E. Franklin, A. Blakers, N. Zin, K. McIntosh, W. Li, Y. Cheng, T. P. White, K. Weber, K. Catchpole, Adv. Energy Mater. 2017, $1700228,1$.

[26] U. W. W. Paetzold, M. Jaysankar, R. Gehlhaar, E. Ahlswede, S. Paetel, W. Qiu, J. P. Bastos, L. Rakocevic, B. S. Richards, T. Aernouts, M. Powalla, J. Poortmans, J. Mater. Chem. A 2017, 5, 9897.

[27] C. D. Bailie, M. G. Christoforo, J. P. Mailoa, A. R. Bowring, E. L. Unger, W. H. Nguyen, J. Burschka, N. Pellet, J. Z. Lee, M. Grätzel, R. Noufi, T. Buonassisi, A. Salleo, M. D. McGehee, Energy Environ. Sci. 2014, 8, 956.

[28] J. Werner, G. Dubuis, A. Walter, P. Löper, S. J. Moon, S. Nicolay, M. Morales-Masis, S. De Wolf, B. Niesen, C. Ballif, Sol. Energy Mater. Sol. Cells 2015, 141, 407.

[29] D. Y. Liu, T. L. Kelly, Nat. Photonics 2014, 8, 133.

[30] G. M. Kim, T. Tatsuma, J. Phys. Chem. C 2016, 120, 28933

[31] Y. Jiang, I. Almansouri, S. Huang, T. Young, Y. Li, Y. Peng, Q. Hou, L. Spiccia, U. Bach, Y.-B. Cheng, M. Green, A. Ho-Baillie, J. Mater. Chem. C 2016, 4, 5679.

[32] M. Anaya, G. Lozano, M. E. Calvo, W. Zhang, M. B. Johnston, H. J. Snaith, J. Phys. Chem. Lett. 2015, 6, 48.

[33] A. Kovalsky, C. Burda, Semicond. Sci. Technol. 2016, 31, 73001.

[34] J. P. Correa-Baena, M. Anaya, G. Lozano, W. Tress, K. Domanski, M. Saliba, T. Matsui, T. J. Jacobsson, M. E. Calvo, A. Abate, M. Grätzel, H. Míguez, A. Hagfeldt, Adv. Mater. 2016, 1, 5031.

[35] U. W. Paetzold, W. Qiu, F. Finger, J. Poortmans, D. Cheyns, Appl. Phys. Lett. 2015, 106, 173101

[36] W. Qiu, T. Merckx, M. Jaysankar, C. Masse de la Huerta, L. Rakocevic, W. Zhang, U. W. Paetzold, R. Gehlhaar, L. Froyen, J. Poortmans, D. Cheyns, H. J. Snaith, P. Heremans, Energy Environ. Sci. 2016, 9, 484.

[37] N. J. Jeon, J. H. Noh, Y. C. Kim, W. S. Yang, S. Ryu, S. II Seok, Nat. Mater. 2014, 13, 1

[38] J. Burschka, N. Pellet, S.-J. Moon, R. Humphry-Baker, P. Gao, M. K. Nazeeruddin, M. Grätzel, Nature 2013, 499, 316.

[39] M. Liu, M. B. Johnston, H. J. Snaith, Nature 2013, 501, 395

[40] F. C. Krebs, H. Chen, J. Mater. Chem. A 2015, 3, 24254.
[41] W. Chen, Y. Wu, J. Liu, C. Qin, X. Yang, A. Islam, Y.-B. Cheng, L. Han, Energy Environ. Sci. 2015, 8, 629.

[42] M. Anaya, J. P. Correa-Baena, G. Lozano, M. Saliba, P. Anguita, B. Roose, A. Abate, U. Steiner, M. Grätzel, M. E. Calvo, A. Hagfeldt, H. Míguez, J. Mater. Chem. A 2016, 60-61, 269.

[43] Q. Lin, A. Armin, R. C. R. Nagiri, P. L. Burn, P. Meredith, Nat. Photonics 2015, 9, 106.

[44] J. M. Ball, S. D. Stranks, M. T. Hörantner, S. Hüttner, W. Zhang, E. J. W. Crossland, I. Ramirez, M. Riede, M. B. Johnston, R. H. Friend, H. J. Snaith, Energy Environ. Sci. 2015, 8, 602.

[45] M. Shirayama, H. Kadowaki, T. Miyadera, T. Sugita, M. Tamakoshi, M. Kato, T. Fujiseki, D. Murata, S. Hara, T. N. Murakami, S. Fujimoto, M. Chikamatsu, H. Fujiwara, Phys. Rev. Appl. 2016, 5, 14012 .

[46] R. Santbergen, R. Mishima, T. Meguro, M. Hino, H. Uzu, J. Blanker, K. Yamamoto, M. Zeman, Opt. Express 2016, 24, A1288.

[47] C. D. Bailie, M. G. Christoforo, J. P. Mailoa, A. R. Bowring, E. L. Unger, W. H. Nguyen, J. Burschka, N. Pellet, J. Z. Lee, M. Grätzel, R. Noufi, T. Buonassisi, A. Salleo, M. D. McGehee, Energy Environ. Sci. 2014, 8, 956.

[48] C.-W. Chen, S.-Y. Hsiao, C.-Y. Chen, H.-W. Kang, Z.-Y. Huang, H.-W. Lin, J. Mater. Chem. A 2015, 3, 9152.

[49] P. Eiamchai, P. Chindaudom, A. Pokaipisit, P. Limsuwan, Curr. Appl. Phys. 2009, 9, 707

[50] M. Filipič, P. Löper, B. Niesen, S. De Wolf, J. Krč, C. Ballif, M. Topič, Opt. Express 2015, 23, A263.

[51] D. A. G. Bruggeman, Ann. Phys. 1935, 416, 636

[52] P. B. Johnson, R. W. Christry, Phys. Rev. B 1972, 6, 4370.

[53] M. Bender, W. Seelig, C. Daube, H. Frankenberger, B. Ocker, J. Stollenwerk, Thin Solid Films 1998, 326, 72.

[54] M. Losurdo, M. Giangregorio, P. Capezzuto, G. Bruno, R. De Rosa, F. Roca, C. Summonte, J. Plá, R. Rizzoli, J. Vac. Sci. Technol., A 2002, $20,37$.

[55] H. Ibach, H. Lüth, Solid-State Physics: An Introduction to Principles of Materials Science, Springer-Verlag, Berlin/Heidelberg, Germany 2010.

[56] L. Sun, P. Hou, Thin Solid Films 2004, 455-456, 525

[57] R. Schölin, M. H. Karlsson, S. K. Eriksson, H. Siegbahn, E. M. J. Johansson, H. Rensmo, J. Phys. Chem. C 2012, 116, 26300

[58] A. Abate, T. Leijtens, S. Pathak, J. Teuscher, R. Avolio, M. E. Errico, J. Kirkpatrik, J. M. Ball, P. Docampo, I. McPherson, H. J. Snaith, Phys. Chem. Chem. Phys. 2013, 15, 2572.

[59] S. Fantacci, F. De Angelis, M. K. Nazeeruddin, M. Grätzel, J. Phys. Chem. C 2011, 115, 23126.

[60] E. H. Anaraki, A. Kermanpur, L. Steier, K. Domanski, T. Matsui, W. Tress, M. Saliba, A. Abate, M. Grätzel, A. Hagfeldt, J.-P. Correa-Baena, Energy Environ. Sci. 2016, 3128, 3128.

[61] M. Saliba, T. Matsui, J.-Y. Seo, K. Domanski, J.-P. Correa-Baena, M. K. Nazeeruddin, S. M. Zakeeruddin, W. Tress, A. Abate, A. Hagfeldt, M. Grätzel, Energy Environ. Sci. 2016, 9, 1989.

[62] X. Li, D. Bi, C. Yi, J.-D. Décoppet, J. Luo, S. M. Zakeeruddin, A. Hagfeldt, M. Grätzel, Science 2016, 353, 58.

[63] G. Yin, A. Steigert, P. Manley, R. Klenk, M. Schmid, Appl. Phys. Lett. 2015, 107, 211901

[64] A. Hoffmann, U. W. Paetzold, C. Zhang, T. Merdzhanova, A. Lambertz, C. Ulbrich, K. Bittkau, U. Rau, Opt. Express 2014, 22, A1270.

[65] A. Abate, T. Leijtens, S. Pathak, J. Teuscher, R. Avolio, M. E. Errico, J. Kirkpatrik, J. M. Ball, P. Docampo, I. McPherson, H. J. Snaith, Phys. Chem. Chem. Phys. 2013, 15, 2572. 